\title{
検索行動調査に基づく検索エレメント 設計に関する一考察
}

\section{A Study on the Design of Retrieval Elements based on an Investigation of User's Retrieval Processes}

\author{
松村 敦 ${ }^{1 *}$, 古川 沙希子 ${ }^{2}$, 宇陀 則彦 ${ }^{1}$ \\ Atsushi MATSUMURA, Sakiko FURUKAWA, Norihiko UDA
}

*1 筑波大学大学院 図書館情報メディア研究科

Graduate School of Library, Information and Media Studies, University of Tsukuba

干 305-8550 茨城県つくば市春日 1-2

E-mail: \{matsumur,uda\}@slis.tsukuba.ac.jp

2 日本アスペクトコア株式会社

NIHON ASPECT CORE INC.

現在，博物館などの持つ多樣な情報資源を共有化し，提供しようとする動きが盛んである．し かし , これまでのシステムは , 共有データの設計の議論が主で , 利用者への提供方法に関する十 分な議論がなされていない.

乥こで本研究では, 資源共有システムにおける情報提供方法を検討するためには, 利用者の検 索行動を詳細に分析する必要があると考え, 検索プロセスの記録とインタビュー・発話分析を組 合せた検索行動調査を行なった .

調査の結果 , 全エレメントを一度に検索できる ANY は利用者の検索支援には重要であること， Title のように格納されている内容の分かりやすいエレメントは効果的に利用できること，Date の ように検索に有効であっても，内部のデータ形式が不明な場合には利用されにくいことなどが分 かった .これらの結果をもとに , 資源共有システムでの検索エレメントの設計についての考察を 行なった。

There are increasing numbers of systems designed to share information resources among different organizations. However, as the main point of discussion of these systems is the method of mapping the metadata element set of each database onto the others', users' viewpoints are kept out of the discussion of constructing systems.

This paper aims to analyze user demands by investigating the actual use of information retrieval systems to examine search methods in shared resource systems. People's retrieval processes were investigated using a cognitive psychological experiment, with protocol analysis and interviews.

Through a detailed analysis of their information retrieval processes, the following results were found: 1) a query that allows searches on all search elements together is effective for users who do not understand the details of either queries or databases; 2) elements such as 'Title', the definition of which is clear and easily understood, are used effectively; 3) even if an element is effective for retrieval, such as 'Date', it is not used when the format of the values in the element is not shown. Based on the results of this investigation, we discuss a method for constructing search elements in resource sharing systems.

キーワード：資源共有，利用者要求，発話思考法，メタデータ，検索インタフェース

Resource Sharing, User Demands, Think Aloud Method, Metadata, Search Interface 


\section{1 はじめに}

博物館や資料館，美術館など樣々な機関 に所蔵される資源がデータベース化され， ネットワークを介して公開されるようにな ってきた .これらのデータベースはこれま て個別に使用されてきたが，近年，多樣な 情報資源を共有し横断的に利用することで， 新しい研究領域の開拓につながるのではな いかなど，資源共有システムへの期待が高 まってきている .

このような背景のもと，各機関は保有す る情報資源にメタデータを付与し資源共有 化に備えはじめている．ところが, 形態の 異なる情報資源から作られた各機関のメ夕 データ形式は必然的に多樣なものとなる． この多樣性は各機関の資源の特性を示すも のであるが , データを共有する際には大き な障害となる．

資源共有化の先進的な研究プロジェクト として総合研究大学院大学の人文科学系の 基盤機関を中心とした資源共有化システム に関する研究がある $[1,2]$.このプロジェク 卜では, Dublin Core[3] (以下 , DC) を1つ の統制されたメタデータとして採用し，全 ての機関のメタデータをこれに対応付ける という手法をとり, メタデータの多樣性に 対処している.ここではこれまで，さまざ まな角度から共有基盤のためのデー夕設計 についての議論が行なわれている $[4,5,6]$. しかしながら，現状ではデータを統一的に 扱うための合意形成と精度の高い対応付け 手法の検討などが焦点であり，利用者がど のようにシステムを利用するかについては， まだ十分議論されていない，例えば，この プロジェクトのプロトタイプシステムでは， DCエレメントを全て提示するインタフェー スを採用している。しかし，利用者が必ず 全ての検索エレメントを駆使して検索を行 なうわけではなく，データの記述のための エレメントと検索のためのエレメントの対
応づけが今後の課題として残されている .

一方で , Google (http://www.google.com/) に代表される Web 検索エンジンと同じよ うに検索エレメントが 1つしかないインタ フェースが多くのデータベースの検索イン タフェースとして採用されはじめている . 一般の利用者が Google のような検索イン タフェースに慣れてしまった現状では，検

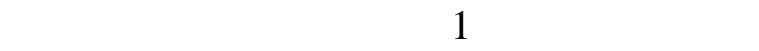
考え方もあるが , 実際の問題解決のために 本当に検索エレメントは 1 つで十分かどう かは明らかではない .

すなわち，現状のシステムの設計は， データの構成を中心として考えられたり， 単純に良く使われるシステムの模倣であっ たりして，光れを使う利用者側の視点が欠 けている . 利用者がどのように検索を行な うか，どのような検索インタフェースが使 いやすいかなどの議論が十分に行なわれて いない . 同樣の問題は , 図書館の目録検索 システム OPACでも起こっており [7]，利 用者の視点からのシステム設計の重要性が 指摘されているが，多樣な異種情報資源を 扱う資源共有システムの設計ではこのよう な視点がとりわけ重要となる .

これまで行なわれてきた検索システム に関する利用者調査には, 利用者の検索口 グを記録し分析する研究がある．OPACや Web 検索システムを主な対象として，使わ れたキーワードなどを分析した研究である $[8,9,10]$. しかし，これらの手法では，利用 者がどの樣な考えをもつて検索行動をとつ たかは間接的にしか分からないという問題 がある．また，ある検索行動をとらなかっ たということは観測できても，谷の理由を 知ることはできない .

一方，利用者の検索行動を細かに観察し 利用者行動を分析する研究もある $[11,12$, 13] . これらの研究の特徵は, インタビュー や検索中の被験者の発話を利用して，個々 の検索行動の詳細な分析を行なっているこ 
とである . 検索の表面的な記録だけではな く，光れ光れの検索行動に対して利用者が どのように考えていたか，どのような状況 であったかを詳しく知ることができる．し かしながら，これらの研究は利用者の要求 を意識したシステム設計という視点ではな く, 利用者行動の特徵の解明が主たる目標 である

乥こで本研究では, 資源共有システムに おける情報提供の方法を検討するために， まずは利用者の検索行動を詳細に分析す る必要があると考えた，弚のために，検索 プロセスの記録をとると同時に , インタビ ユーと発話分析を組合せ，利用者がどのよ うな要求をもってシステムを利用するかを 明らかにする、特に検索エレメントの使用 方法と光の理由に焦点をあてることで資源 共有システムの検索インタフェースに対す る具体的な問題の発掘と改善方法を明らか にすることを目指す．

\section{2 検索行動調査}

\section{1 調査概要}

本調査は，利用者の検索行動がどのよう な意図や状況から行なわれているかを明ら かにし，これをもとに利用者の視点を採り 入れた検索エレメントの設計を行なうこと を目的としている。

調査は, 検索実験を中心とし, 光の前後 に検索行動の意図や利用者自身の状況を把 握するための事前質問とインタビュー調査 を行なった . 検索実験は, 主に被験者の検 索行動をとらえるために行なった . 使用し た検索キーワードと検索エレメント，光れ らを使用した理由や状況を観察と前後のイ ンタビューにより取得した。

調査対象は, 研究者 4 名, 図書館員 1 名, 大学院生 1 名, 学部学生 1 名, 大学事務職 員 1 名の計 8 名である.一般の大学事務職
員から学生, 研究者まで比較的広い範囲を 対象として調査を行ない，より多くの層の 検索行動についての知見を得ることを目指 した . 以下，これらの調査についての詳細 を説明する。

\section{2 利用者の特徵の調査}

被験者の知識レベルなどの特徵は，検索 行動に影響する可能性がある．本調査では， 検索実験前後にアンケートとインタビュー を行ない，被験者の特徵をまとめた．

調査項目は,「検索エレメント」「検索課 題に関する知識」「専門領域」である . こ れらの項目について個々の被験者に対しア ンケートとインタビューを行なった「検索 エレメント」は実験システムの検索エレメ ントであるDCの 15 項目に関する知識を聞 いた「検索課題に関する知識」は以降で述 べる検索課題の内容に関連する知識につい ての簡単な問題に解答してもらった「専門 領域」は被験者の専門領域／職業である．

\section{3 検索実験}

検索実験は等しい検索条件下での検索シ ステムの利用方法の違いを明らかにするた めに，検索システムと検索課題を指定し， 発話思考法を用いて行なった。なお，検索 実験中の発話や検索画面の樣子は , ビデオ カメラ等を用いて記録した . 実験環境はで きるだけ各被験者の普段の環境に即したも のとなるように , 各被験者の居室もしくは 機関内の施設で行なった .

実験システム 実験で使用した検索システ ム (以下, 実験システム) は, 先に述べた総 合研究大学院大学のプロジェクトで構築さ れたシステムであり，複数の研究機関等が 蓄積·提供する多樣な人文科学研究資源デー 


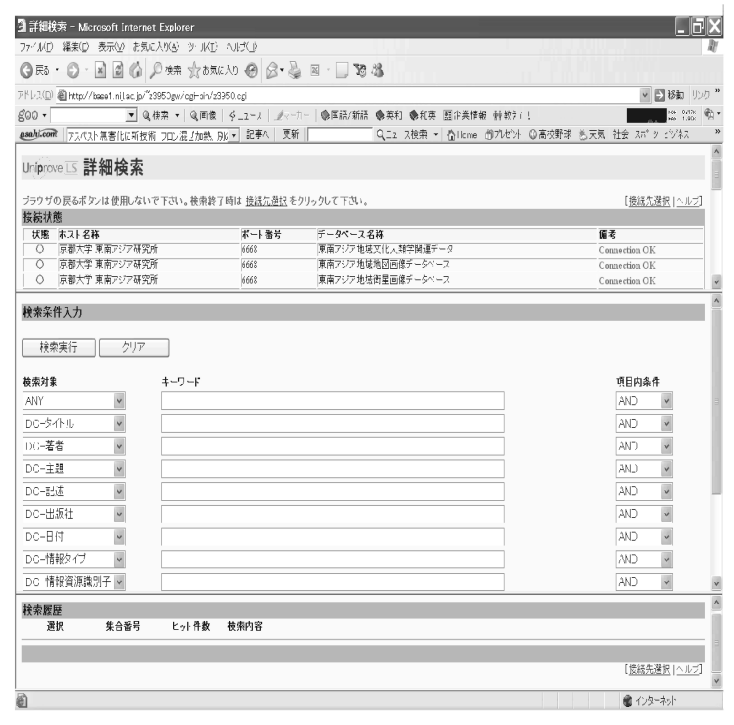

図 1: 実験システムの検索画面

タベースを横断検索できる．図 1 に実験シ ステムのインタフェースを示した .上中下 の3つのフレームに分かれており，上段は 各データベースへの接続状況, 中段は検索 エレメントと検索ボタンを配置した検索機 能 , 下段は検索結果と履歴の表示となって いる.中断の検索エレメントは, DC の基 本 15 エレメントと，15 エレメント全てを まとめて検索できる ANY というエレメン 卜か設定されている .

ただし，DCの 15 検索エレメントと各 機関の提供するオリジナルデータベースの 項目との対応付け (マッピング) は各機関 の考え方よって行われている．たとえば， ANY は基本的には DC の全てのエレメン トのコピーであるが，実際には各機関が検 索に必要と考えるエレメントのみが提供さ れている .

また，個々のエレメントについても資料 (史料) の性質からくるマッピングの摇れ がある．たとえば，TYPEには国立歴史民 俗博物館の館蔵資料データベースでは「実 物」か「模造」かの区別, 国立民族学博物 館の標本資料データベースでは DCMI Type Vocabulary で定義された語彙から選択した $\ulcorner$ physical object」がマッピングされている が, 国文学研究資料館の場合は収録データ ベース名が記載されているものが多い．ま た，日付情報は機関毎，データベース毎に Date と Coverage に分散してマッピングさ れている.現状では，このようなエレメン トのマッピングに関しての合意を取ること は難しく，本研究ではこのように本質的に マッピングに摇れがあるシステムの利用を 前提として評価を行なう.

検索課題 検索実験では被験者に図 2 に示 した 3つの検索課題を与えた .

\section{以下の検索要求を満たす資料を探して ください.}

1. 醍醐天皇の命により紀貫之, 紀友 則か編者をつとめた勅撰集は何か? 㫕れは現存しているか?しているな らば，所蔵館を1つ*知りたい。

2. 室町時代に書かれた書状のうち, 足 利氏に関わるものは残っているか? 残っていれば, 弚のうちから一つ選 び，炎の書状に記載されている人 物の研究資料を探したい.

3. 俳人自身が俳句について論じてい る文献にはどのようなものがある か? 1 人の俳人†を任意に選び，リ ストアップしたい.

†調査当初は「どの資料館で見ることが出来る か」としていたが、所蔵館を1つ」に修正した． †調査当初は「2人の俳人」としていたが，「1 人の俳人」に修正した.

図 2: 検索課題

検索を行なうにあたつて次の条件を与え た . まず，キーワードなどを調べたい場合 
には自由に検索ツール (データベース ,Web 検索エンジン等) を使って調べても構わな いこととした .これは, 検索課題に関す る知識が無く，検索できない状況に陥らな いようにするためである．ただし，外部の ツールだけで検索を終えないように制限す るために, 最終的な結果は実験システムを 利用して探すという条件をつけた .これに よって, 被験者が共通の実験システムを利 用した際の検索エレメントの利用方法を観 察し取得できるようにした .

また，被験者からの質問に答えると誘導 になる可能性があるため, 検索課題の解釈 は被験者自身に行なってもらった . 同樣の 理由で, 検索の終了も被験者自身の判断に 任せ，検索結果に納得した場合か，あきら めた場合に被験者自身て終了の合図をして もらった .

発話思考法 検索実験では発話思考法を用 いた．発話思考法とは，頭に浮かんだこと を全て口に出しながら操作してもらう方法 である.これによって，観察では分からな い利用者の検索時の考えを明確にすること が可能となる.ただし, 発話思考法は被験 者に大きな負担を強いる手法である．また， 自身の行動を説明することが得意な人と不 得手な人では発話量に差が出る. 兴のため， 発話が带ったり，あきらかに考えているの に発話がない場合には, 調査側で「今, 何 をお考えですか?」という質問をして発話 を促した。

\section{3 調査結果}

ここでは調査結果を利用者の特徵, エレ メントの使用回数を中心とした使用状況， 各エレメントを使用した理由に分けて示す．

\section{1 利用者の特徵}

検索実験と並行して行なつた利用者自身 に関する調査結果を示す。

検索エレメント 検索エレメントの評価 は, DCに関する既知の事項についてのアン ケート調査の結果である . 各被験者が知っ ているエレメント名およびエレメント内容

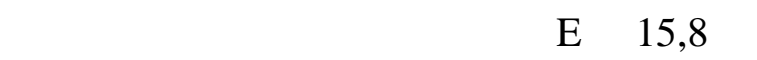
あるのはエレメント名は 15 項目全て知っ ているが, 弚の内容は8 項目しか知らない ということを表している

検索課題に関する知識 検索課題に関する 事前知識をどれくらい持っているかを把握 するために実施した簡単な問題への解答結 果よりまとめた . 知識の程度は $\bigcirc \triangle \times の 3$ 段階て評価した . 被験者 $\mathrm{H}$ は全ての課題に 対して，関連する知識を非常に詳しく持っ ていた。課題毎に見ると, 課題 3 に関して

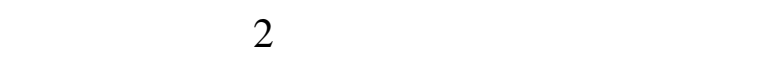
事前知識は多かった .

専門領域 専門領域は, 実験終了後のイン タビューで聞いたものである、検索課題に 関連する資料領域の専門家は被験者 $\mathrm{H}$ のみ であった、また，被験者 $\mathrm{E} は ，$ 現在はデー 夕解析が中心であるが, 以前歴史資料にか かわりを持っていた .

\section{2 エレメントの使用状況}

表 2 に, 各検索エレメントについて使用 した被験者と使用回数を示した .

ANY は 8 人中 7 人の被験者が使用し, 使 用回数も 112 回と個別のエレメントの使用 回数よりかなり多い，一方, 個別のエレメ ントでは, 8 人中 7 人がTitle, Creator を使 用し, 使用回数も他のエレメントに比べて 
表 1: 被験者の特徵

\begin{tabular}{|c|c|c|c|c|c|}
\hline \multirow[t]{2}{*}{ 被験者 } & \multirow{2}{*}{$\begin{array}{c}\text { 検索 } \\
\text { エレメント }\end{array}$} & \multicolumn{3}{|c|}{ 課題に関する知識 } & \multirow[t]{2}{*}{ 専門領域／仕事 } \\
\hline & & 課題 1 & 課題 2 & 課題 3 & \\
\hline A & 15,15 & $x$ & $x$ & $\triangle$ & $\begin{array}{l}\text { 歴史・博物館に関わる情報システ } \\
\text { ムの構築と評価 }\end{array}$ \\
\hline B & 6,4 & $x$ & $\triangle$ & 0 & $\begin{array}{l}\text { 図書館職員 · 大学院にて情報探索 } \\
\text { 行動のモデル化 }\end{array}$ \\
\hline $\mathrm{C}$ & 0,0 & $x$ & $x$ & 0 & $\begin{array}{l}\text { 図書館情報学 . 卒業研究で音声情 } \\
\text { 報処理 }\end{array}$ \\
\hline $\mathrm{D}$ & 15,15 & O & $\triangle$ & O & 標本資料の記述と提供システム \\
\hline $\mathrm{E}$ & 15,8 & $x$ & $x$ & $\bigcirc$ & $\begin{array}{l}\text { アーカイブズにおける EAD の適 } \\
\text { 用 (過去に民衆史料史) }\end{array}$ \\
\hline $\mathrm{F}$ & 0,0 & $x$ & $x$ & $x$ & 事務職員 ～～～～～～～～ \\
\hline G & 14,14 & $\triangle$ & $\triangle$ & 0 & $\begin{array}{l}\text { 図書館情報学 . 卒業研究で電子図 } \\
\text { 書館 }\end{array}$ \\
\hline $\mathrm{H}$ & 15,2 & 0 & $\bigcirc$ & 0 & $\begin{array}{l}\text { 中世古文書の整理・公開 (展示) } \\
\text { データベースス作成 }\end{array}$ \\
\hline
\end{tabular}

多かった．次に多いのがDescription と Subjectであった . また, Date , Publisher, Language, Identifier, Source, Rights は使用した 人がいなった .

次に, 利用者別で見ると, 被験者 D は 一度もANYを使用しなかったのに対して， 被験者HはANYだけしか使用しなかった . 残りの被験者は ANY と個別のエレメント の両方を使用した . 特に被験者 $\mathrm{A}$ と $\mathrm{G}$ は 使用したエレメントの種類が多く，共に 8 種類であった .

\section{3 エレメント 使用の理由と意図}

次に, 発話とインタビューから抽出され た検索エレメントを使用した理由を示す．

まず，ANYを使用した理由をまとめたの が表3である.各被験者がANY を使用した 理由で該当する場合に○を入れている．な お，被験者 D は ANYを一度も使わなかっ
たため掲載していない .

ANY を使った全ての被験者は，「該当す るエレメントが特定できない」という理由 をあげている．また，被験者 $\mathrm{F}$ 以外は「幅 広く検索して樣子を見るため」という理由 もあげており，この 2 点がANYを使用す る大きな理由であった .

次に，個別のエレメントに関する発話や インタビューの結果について示す . 個々の 被験者の発話をまとめたところ，個別のエ

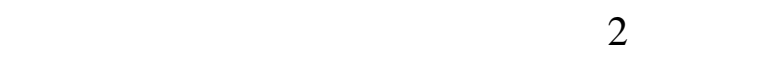
合があることが分かった．1つは，弚のエ レメントを使えば良いことを明確に理解し ていた場合であり，もう1つはエレメント の意味する内容を正確に理解せずに使って いた場合である．一方，使用しなかったエ レメントの中には，使おうとしていた場合 もあった .ここでは，これらの使用状況を 乥れ光れ「明確な理解での使用」「曖昧な 理解での使用」,「使用不能」と定義する． 各エレメントと光の使用状況に該当した被 
表 2: 被験者毎のエレメントの使用回数

\begin{tabular}{|l||r|r|r|r|r|r|r|r|r||r||}
\hline \multicolumn{1}{|c||}{ DC エレメント名 } & \multicolumn{6}{|c||}{ 被験者別使用回数 } \\
\cline { 2 - 8 } & A & B & C & D & E & F & G & H & \\
\hline \hline ANY & 15 & 5 & 22 & & 9 & 19 & 27 & 15 & 112 \\
\hline Title & 1 & 12 & 2 & 5 & 2 & 2 & 10 & & 34 \\
Creator & 2 & 4 & 1 & 5 & 2 & 1 & 18 & & 33 \\
Subject & 1 & & & 2 & & 1 & 2 & & 6 \\
Description & 2 & & & 3 & & & 2 & & 7 \\
Type & 2 & & & & & & 3 & & 5 \\
Format & & & & & & & 3 & & 3 \\
Contributor & & & & & & & 1 & & 1 \\
Relation & 1 & & & & & & & & 1 \\
\hline Publisher & & & & & & & & & 0 \\
Date & & & & & & & & & 0 \\
Identifier & & & & & & & & & 0 \\
Source & & & & & & & & 0 \\
Language & & & & & & & & & 0 \\
Coverage & & & & & & & & & 0 \\
Rights & & & & & & & & & 0 \\
\hline
\end{tabular}

表 3: ANYを使用した理由

\begin{tabular}{|c|c|c|c|c|c|c|c|}
\hline \multirow[t]{2}{*}{ 理由 } & \multicolumn{7}{|c|}{ 被験者 } \\
\hline & A & B & $\mathrm{C}$ & $\mathrm{E}$ & $\mathrm{F}$ & G & $\mathrm{H}$ \\
\hline 該当するエレメントが特定できない & O & O & 0 & 0 & 0 & 0 & O \\
\hline 幅広く検索して樣子を見るため & 0 & O & 0 & O & & 0 & O \\
\hline 特定のエレメントを想定 & & & $\bigcirc$ & & & $\bigcirc$ & \\
\hline 検索に失敗したため条件を緩くする & & 0 & O & & & & \\
\hline 網羅的に検索するため & & & & & & & 0 \\
\hline 入れ方が分からない & & & & & & 0 & \\
\hline 無意識 & & & O & & & & \\
\hline
\end{tabular}


表 4: 個別のエレメントの使用状況

\begin{tabular}{|l||l|l|l|}
\hline DC エレメント & $\begin{array}{l}\text { 明確な理解での } \\
\text { 使用 }\end{array}$ & $\begin{array}{l}\text { 曖昧な理解での } \\
\text { 使用 }\end{array}$ & 使用不能 \\
\hline \hline Title & B, C, D, E, G & F & \\
Creator & A, B, C, D, E, G & F, G & \\
Subject & D, G & A, F & G \\
Description & A, G & A & G \\
Contributor & & G & \\
Date & & A, G & A, G, H \\
Type & & G & G \\
Format & & & G \\
Source & & A & \\
Relation & & & A \\
Coverage & A, C & \multicolumn{2}{|l}{} \\
\hline
\end{tabular}

験者をリストアップしたものが表4である． Title は 5 人，Creator は 6 人の被験者が， エレメントの意味を明確に理解して使用し た .一方，Contributor, Date，Type，Format, Source, Relation の各エレメントは曖 昧な理解のままて使用したか，使用されな かったエレメントである.特に, Date は誰 も使用することはなかったが 3 人の被験者 が使用しようとしたエレメントであった . また，Subject, Description, Coverageの 3 つのエレメントは, 明確な理解の上で使用 された場合と曖昧な理解での使用，もしく は使用不能であった場合の両方があった .特 に，同じ被験者でも両方の場合があった .

ユーザ毎に見ると， $\mathrm{F}$ は全てのエレメン 卜を暧昧な理解で使用していた .また，A と $\mathrm{G}$ は曖昧な理解での使用や使用不能の工 レメントが多かった .

次に，弚れ光れのエレメントの使用状況 にかかわる発話およびインタビュ一内容を まとめた(表 5 , 表 6 , 表 7).なお, 主な発 話内容の欄の英字と数字の組合せは被験者 と課題番号を表す.例えば，B2であれば被
験者 B の課題 2 での発話内容を表す．

表 5 から，明確な理解でエレメントを使 用できた主な理由は，Creatorの「入力場所 とキーワードが分かっていた」のようにエ レメント内容をはじめから明確に想像でき ている場合と Coverage の「検索結果を見 て時代と理解した」のように検索していく 過程でどのようなエレメントであるかが明 確になったという2つであった .

また, 曖昧な理解でエレメントを使用し た理由は，主に2つであった（表 6)．1つ は, Creator の「何処に入れるか分からな

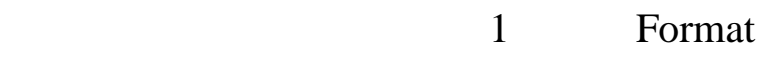
の「書状がType と Formatか迷うが入れた」 のような場合であった .

一方，エレメントが使われなかった理由 は, 表 7 の発話内容にあるように次の $2 つ$ であった . 1つは, Subjectの「Description との違いが分からない」やDateの「Coverage との違いが分からない」のように, $2 つ$ のエレメントの区別ができない場合であっ た .もう1つは，Dateのように「入力方法 が分からない」場合であった . 
表 5: 検索エレメントの使用状況と主な発話内容 .(明確な理解で使用した場合)

\begin{tabular}{|c|c|c|}
\hline DC エレメント & 被験者 & 主な発話内容 \\
\hline Title & $\mathrm{B}, \mathrm{C}, \mathrm{D}, \mathrm{E}, \mathrm{G}$ & $\begin{array}{l}\text { google で足利と書状が表題に現れると分かっ } \\
\text { ていた (B2) } \\
\text { msn で古今和歌集と分かった (G1) } \\
\text { 検索結果を見て入れる場所を理解した (C2) }\end{array}$ \\
\hline Creator & $\mathrm{A}, \mathrm{B}, \mathrm{C}, \mathrm{D}, \mathrm{E}, \mathrm{G}$ & $\begin{array}{l}\text { 検索結果から紀貫之の場所を学習した (B1) } \\
\text { 著者で絞り込みたい (C3) } \\
\text { 入力場所とキーワードが分かっていた (D1) } \\
\text { 一番確度が高い (E3) }\end{array}$ \\
\hline Subject & $\mathrm{D}, \mathrm{G}$ & $\begin{array}{l}\text { 足利を主題としたものを探す (D2) } \\
\text { 主題に入っていればその人に関するものなの } \\
\text { で }(\mathrm{G} 2)\end{array}$ \\
\hline Description & $\mathrm{A}, \mathrm{G}$ & $\begin{array}{l}\text { 差出，宛先が入っていることを知っていた } \\
\text { (A2) } \\
\text { ここも足利が入っている可能性があると知っ } \\
\text { ていた (D2) }\end{array}$ \\
\hline Coverage & $\mathrm{A}, \mathrm{C}$ & $\begin{array}{l}\text { 途中で内容が分かった · 絞り込んで調べます } \\
\text { (A2) } \\
\text { 検索結果を見て時代と理解した (C2) }\end{array}$ \\
\hline
\end{tabular}


表 6: 検索エレメントの使用状況と主な発話内容 (暧昧な理解で使用した場合)

\begin{tabular}{|c|c|c|}
\hline DC エレメント & 被験者 & 主な発話内容 \\
\hline Title & $\mathrm{F}$ & $\begin{array}{l}\text { 前の課題でANY で失敗したので, タイトル } \\
\text { に入れて良いか分からず }(\mathrm{F} 3)\end{array}$ \\
\hline Creator & $\mathrm{F}, \mathrm{G}$ & $\begin{array}{l}\text { 何処に入れるか分からなかった (F1) } \\
\text { 友則は Contributor かもと思いつつ (G1) }\end{array}$ \\
\hline Subject & $\mathrm{A}, \mathrm{F}$ & $\begin{array}{l}\text { 適当な場所が分からず試した (A1) } \\
\text { 何処に入れるか分からなかったので勅選集を } \\
\text { 主題に (F1) }\end{array}$ \\
\hline Description & A & 適当な場所が分からず試した (A1) \\
\hline Contributor & G & 貫之と友則は違うと思ったので (G1) \\
\hline Type & $\mathrm{A}, \mathrm{G}$ & $\begin{array}{l}\text { 適当な場所が分からず試した (A1) } \\
\text { Type の意味が分かっていない } \\
\text { ものに絞りたい }(\mathrm{G} 3) \\
\text { 論じている }\end{array}$ \\
\hline Format & G & 書状がType か Format か迷うが入れた (G2) \\
\hline Relation & A & 可能性のあるフィールドを探すため (A1) \\
\hline
\end{tabular}

表 7: 検索エレメントの使用状況と主な発話内容 (使われなかった場合)

\begin{tabular}{|c|c|c|}
\hline DC エレメント & 被験者 & 主な発話内容 \\
\hline Subject & G & Description との違いが分からない (G2) \\
\hline Description & G & Subject との違いが分からない (G2) \\
\hline Date & $\mathrm{A}, \mathrm{G}, \mathrm{H}$ & $\begin{array}{l}\text { 入力方法が分からない }(\mathrm{A} 1, \mathrm{G} 1, \mathrm{H} 2) \\
\text { Coverage との違いが分からない }\end{array}$ \\
\hline Type & G & $\begin{array}{l}\text { 原本と関係があるか分からない }(\mathrm{G} 1) \\
\text { 書状と関係あるかもしれないが Format を選 } \\
\text { 択 (G2) }\end{array}$ \\
\hline Source & G & $\begin{array}{l}\text { 原本と関係があると思ったが検索結果をみて } \\
\text { 違った }(\mathrm{G} 1)\end{array}$ \\
\hline Coverage & $\mathrm{A}, \mathrm{D}$ & Date との違いが分からない (A1) \\
\hline
\end{tabular}




\section{4 考察}

ここでは，これまでに示した調査結果を 踏まえ, 利用者の視点を考慮した検索エレ メントセットについて考察する .

\subsection{ANY エレメントの有効性}

今回の調査で , 全てのエレメントを区別 なく検索できる検索エレメントANYは, 被 験者 D以外の全ての被験者が使用し, 使用 回数も非常に多かった (表 2). 使用した理 由 (表3) を見ても，「広く引つかけるため」 や「樣子見」など個別の検索エレメントに 縛られずに検索したい場合や，「どの項目 に入れて良いか分からない」「検索に失敗 したため」，あるいは「入れ方が分からな い」のように困った時や手詰りの場合にも 有効であることが分かる .このように，利 用者が意図をもって ANYを使用している ことを考えると，Googleのような検索エン ジンの影響のみを考慮してインタフェース を決めるのは問題であることが分かる .た だし，ANYを使わなかった被験者 D がイ ンタビューで「ANYしか出ていなければ ANYを使ったかもしれない」と話してお り，またCも ANYを使用した理由に「無 意識」とあり, 明確な意図をもって使用し ない場合もあることがうかがえる .このよ うな例に広く普及している検索エンジンの インタフェースの影響があるかどうかにつ いては,さらに調査を必要とするであろう．

一方，ANY だけでは十分でないことは， ANY しか使わなかった被験者 Hの検索行 動の理由から読みとれる．HはANYしか 使わなかった理由として「個別のエレメン 卜の内容か明確でなく，信頼できない」と インタビューで答えている．これは裏を返 せば「個別エレメントの内容か明確であれ ば使用する」ということである．実際，H が普段から利用しており詳しく内容を知っ
ている国立歴史民俗博物館の館蔵資料デー タベースに関しては，実験中に「資料名称」 という個別エレメントで検索を実行してい る。また，検索実験中の発話でも「日付の ところで絞れるならば室町時代と指定した いところ (中略) どのように入れると室町時 代になるのか分かりません」と言い, Date の使用をあきらめている .これらのことか ら, ANY以外にも個別エレメントが必要 であると言える

\section{2 個別のエレメントの有効性}

前節で述べたように，検索エレメントと してはANYのみでは十分でない .では ,ど のようなエレメントが必要であろうか . 個 別のエレメントは使用回数からも分かるよ うに，使いやすいものと光うでないものに 分かれる.

Title と Creator は, ほとんど全ての人が 最も多く使用し，また，意味を明確に理解 して使用している. 基本的で分かりやすい これらのエレメントは, 使いやすいと考え られる.実際、足利と書状が表題に現れる と分かっていた」や「著者で絞り込みたい」 に現れているようにエレメントの選択に迷 いがないことが多い(表 5).したがって，こ れら 2 つエレメントを検索インタフェー スに組み込むことは有用であり，利用者の 検索行動を支援できると考えられる．

Subject と Description は, 特定の被験者 に比較的多く使用されているが, 必ずしも 明確に理解して使用されていたわけではな い(表 2 ，表 4). 入れるところが分からな くて試す場面や(表 6), 両者の違いが分か らず使うことをあきらめる場面が多く見ら れた (表 7).しかし, 关れでもこれらの工 レメントが多く使用されたのは，「足利を 主題としたものを探す」(表 5) に現れてい るように，被験者が Subjectや Description に対して内容にかかわる検索を期待してい 
たからと考えられる．すなわち，Subjectや Descriptionのような内容に関する検索エレ メントへの必要性か現れていると言えよう.

一方，一度も使われなかったエレメント は本当に必要ないかというと，光うではな いこともある . Date に関する発話には「入 力方法が分からない」や「Coverage との違 いが分からない」とあり, フォーマットが 不明なことと紛らわしいエレメントの存在 が使用不能となった理由であることが分か る「検索結果をみて違った」(表 7 , Source $)$ とあるように確かに必要でなかったため使 用されなかったエレメントもある.しかし， 少なくとも Dateの場合は, 検索に有用であ ると考えていても，使い勝手が悪いために 使用できなかったということが複数の被験 者の発話から明らかになった。

\section{3 利用者の特徵と 検索エレメン 卜}

前節までは，被験者の全体の傾向からみ たエレメントセットの考察であったが , こ こでは光れ光れの被験者の特徵に応じた検 索エレメントについて考察する .今回の調 査で, 検索エレメントの理解, 検索システ ムの利用経験の違いか検索エレメントの使 い方に影響があることが分かった .

本調査では, 実験システムの検索エレメ ントとして採用した DCの 15 項目につい ての理解度を事前質問により調査した . 光 の結果, 被験者のうち $\mathrm{A}, \mathrm{D}, \mathrm{G}$ の 3 名が 15 項目ともよく理解していることが分かっ た .これらの被験者は他の被験者と比べて 多くのエレメントを使い分けていた(表2). したがって, 検索エレメントを理解してい る人は, 複数のエレメントの使用に抵抗が なく，これらを提示することで検索の利便 性をあげることができると言える．

一方, DCの15 項目を全く知らなかった
のは被験者 Cと Fであつた .このうち被験 者 $\mathrm{F}$ は，日常の検索でも Google などを使 用しており, 複数のエレメントを使用した 検索をした経験がほとんどないことがイン タビューで分かった．検索実験では，どの エレメントに入力して良いかの判断ができ なかったことに加え, エレメント毎に表示 された検索結果を理解できず検索をあきら めてしまっていた .このように, エレメン 卜を理解しておらず，検索システムの利用 経験が浅い場合には，インタフェースに複 数の検索エレメントを配置することは害に しかならないことが明らかである .このよ うな利用者が , 検索エンジンの普及にとも ないどの程度増加しているかは明らかでは ないが, 利用者が検索経験の低い人に限ら れるような場面では，検索エレメントが 1 つだけのインタフェースを提供することも 1 つの方法として考えても良いだろう.

これに対して，同じDCの 15 項目を理 解していなかった被験者 $\mathrm{C}$ は, 複数のエレ メントを使用した検索を日常的に行なって おり，また，検索結果のエレメント別の表 示形式も見慣れていた. 弚のため, 実験シ ステムのエレメントの意味が分からなくと も，検索結果をみているうちに，システム にどのような形式で情報が格納されている かを比較的容易に推測できるようになった . つまり，被験者 Cのように複数のエレメン 卜を使用した検索になれている場合は, 学 習効果が期待されるため個別のエレメント を複数配置するインタフェースも有効であ る可能性が高いと言えるだろう．

一方，「検索課題に関する知識」および 「専門領域」と検索エレメントの使用との 間には明確な因果関係は見られなかった . これは, 内容に関する知識よりも検索シス テムの利用に関する知識の影響が大きいと いう結果ともとれる.しかしながら，被験 者の数も少なくこのような傾向が一般的か どうかを明らかにするには, さらなる調査 
を行う必要がある。

\section{4 エレメント 理解のための支援}

以上 ,インタフェースに提示する各エレ メントの是非について考察したが, ここで はより効果的にエレメントを提示するため の指針について，個々の利用者の検索行動 をもとに考察する．

利用者がエレメントをうまく使用できな かったのは, エレメント光のものが分から ないという場合と，他のエレメントと紛ら わしいという場合があることは述べてきた . いずれにしても，個々のエレメントの意味 についての説明が必要であることは確かで ある。また，ANYに対しても光の意味を 説明する必要がある . 今回の実験では，あ らかじめ ANY の意味については説明して いるため，説明なしにANYを提示した場 合に同樣の検索行動を行なうかどうかは自 明ではない．また，被験者 $\mathrm{F}$ の場合には， 事前説明だけでは ANY の意味を理解でき ていなかったことがインタビューで分かっ ている . 実験中はANYを Google と同じよ うな検索密だと思っただけで, 弚れが全て のエレメントを検索するような仕組みであ るという理解はしていなかった .このよう なことは TitleやCreator のように , 誰でも 理解して使えると思われるエレメントでも 同樣である.実際，被験者Fのように Title で迷うこともあり(表 6)，また，Creatorは Contributor との区別か問題となる可能性が ある(表 7).これらのことも考慮して，検 索エレメントの説明は必須であると考えて 良いだろう。

一方で, 検索エレメントの意味だけが分 かっても十分ではない. 被験者 $\mathrm{A}$ と $\mathrm{G}$ は DCの 15 項目を全て理解していたにもかか わらず, 多くのエレメントを曖昧な理解の まま使用する傾向があった (表4). 例えば，
表 6 の G の発話にある「研究資料が Type かな」や「書状がType か Format か迷うが 入れた」は,「研究資料」や「書状」という キーワードと検索エレメントの対応関係が 分からないとういうことである.他に多く 発話されている「何処に入れるか分からな い」というのも同樣の理由であろうと推測 される . 同じ状況は, Dateが使えなかった という場面でも起きている。こちらは，エ レメントにキーワードを対応付けられない のではなく，光のエレメントに格納された データの形式が分からないために使用でき なかったことが発話から分かる(表 7).

このように, エレメントの定義を理解し ているだけでは, 個別の検索エレメントを 使いこなすことは難しい，実際に対象とな つているデータや検索課題によってエレメ ントとの対応関係に曖昧さが生じることが 原因と考えられる .このことは資源共有シ ステムのデータ設計の際のメタデータの対 応付け問題と同種の問題である $[4,5,6]$.

この場合の解決策には，例示によるサ ポートか有効である．これは明確な理解で 使用した場合の発話に，検索結果を見て理 解したというものが多いことからも分かる (表 5). 弚の際, 複数の異なる情報資源を 共有するようなシステムの場合には，各情 報資源の内容 , 形式を例示する必要があり， どのようなインタフェースで害現するかに ついてはまだ多くの課題が残されている.

\section{5 関連研究との比較}

人間文化研究機構 (http://www.nihu.jp/) でも独自に研究資源共有化システムの構築 をすすめており，実証実験が行なわれてい る.この実証実験の事前調査として，本研 究で扱った実験システムの評価が行なわれ ている [14] . ただし，この評価は本研究の 調査後に行なわれており，厳密に同じシス テムの評価ではない，評価項目は, $「 \mathrm{DC} メ$ 
タデータの有効性」，「マッピングにおけ る CROSSWALK の有効性」,「検索精度」， 「ユーザインタフェース」と多岐にわたる が , 検索エレメントの設計に関する評価は 「DCメタデータの有効性」に含まれている． 被験者は, 人文科学系の大学院生 4 名とシ ステムエンジニア 5 名であり，実際にシス テムを利用したうえでの評価である．9名 の評価結果として，横断検索のためのANY やDCの各検索エレメントは, 大杂倠把な検 索には利用価值が高い一方で, 内容が分か りにくい, 例示が必要であるとの意見が示 されている.特に, Date エレメントでの例 示やデータ統一の必要性が示されている. これらの結果は, 本研究の利用者行動調査 から観察されたものと一致する.しかし， 実際の検索行動の詳細を調査したものでは なく，DCの個別のエレメントの重要性や 必要性については言及していない．このよ うに, 人間文化研究機構の資源共有化シス テムにおける利用者調査は，まだ，はじめ られたばかりであるが , 資源共有化システ ムの構築と並行して利用者に関する調査も 行なうようである . 本研究のアプローチと 弚の結果は，このようなプロジェクトの調 査に活かされると期待される .

また，情報資源の共有システムの構築 例として国立情報学研究所のメタデー タ・データベース共同構築事業がある (http://www.nii.ac.jp/metadata/) .この事業 は, 大学の発信する情報資源を中心とした ネットワーク上の学術情報資源の総合目録 を，共同で構築することを目的としたもの である．また, 学術機関リポジトリの整備 を主要な目的の 1 つとしてあげており, 学 術機関リポジトリ構筑ソフトウェア実装実 験プロジェクト (NII-IRP) として活動がす すめられている .

対象とする情報資源は, 研究論文やソフ トウェア, 電子辞書, 電子教材, データベー ス，Webページ等樣々であり，必然的に異
種情報資源の共有化のための議論が行なわ れている.特に, 機関リポジトリ構築ソフ トウェアの実装実験を中心にすすめており， さまざまな活動が行なわれている .

この事業では , 情報資源を DC (と炎の拡 張)によって記述しており，記述のための ガイドラインも国立情報学研究所によって 詳しく示されている.しかし，メタデータ の記述と品質管理は作成機関に任されてい るため，機関毎に記述のばらつきがみられ るなどの問題が指摘されている [15] .

このようなメタデータの品質管理の問題 に関しては今後の課題とする一方で, 情報 資源の横断検索には, 大学 Web サイト資源 検索 JuNii (http://ju.nii.ac.jp/) を提供してい る . JuNii の検索インタフェースは密が1つ だけのシンプルなもので, 検索対象は Title, Creator, Publisher, Subject, Description のみ である．また，初期検索後の機能として， サイト毎やジャンル毎の絞り込みのみが提 供されているが, ジャンルが比較的細かく 分類されており，絞り込みには有用である． このようなインタフェースは, Webサーチ エンジンの普及という流れに沿ったものと 思われるが , 絞り込みの対象エレメントと 検索対象エレメントの選択に関する評価は なされておらず, 兴の妥当性の評価が必要 である.特に, 本研究や人間文化研究機構 の評価において重要視されていた時間に関 するエレメントへのアクセスが無い点につ いては検討すべきであろう．また，今後こ の事業の普及が進み，膨大なデータが登録 されるようになれば, 詳細な検索エレメン 卜を利用して検索を試みたいと考える利用 者も出てくる可能性がある. とのような時 に，利用者にとって適切なエレメント設計 を考えるためには利用者の調査を基にする 本研究のアプローチが有効であると考える．

一方, 本手法のような利用者の行動を直 接観察し，利用者要求を抽出する手法は， ユーザ中心設計 (User Centered Design) と 
呼ばれるシステム設計手法の一部と位置付 けることも可能である .ユーザ中心設計と は, 利用者の理解・システム設計・評価を 繰り返し, 利用者の視点を密接に関連付け てシステムを作成する方法である．これを 実際のシステム開発に結びつけた例として よく知られたものに, 学術文献を対象とし た Elsevier 社の SCOPUS[16]がある .

SCOPUS における利用者調査は世界の 21 機関 302 名の研究者と図書館員を対象とし た大規模なものであり，乥のフィードバッ クも膨大である .

この中で, 検索開始方法の観察から「幅 広い検索から絞りこんでいく」検索行動を ほとんどの研究者が好んでいるという結果 が示されている.さらに最初の検索行動に 着目すると，1〜3語のキーワード検索か 著者検索がほとんどで他のエレメントを利 用しないという. 幅広い検索のためにキー ワード検索を利用するのは, 本研究の結果 でANYを選択する行動の理由と同等であ るが , 検索の初期にこのような行動が起こ る傾向については本研究の調査結果にも 多く現れてはいるものの, 被験者とタスク (検索課題) 数が少ないため明確な結論と は言えない .

また , 検索フォームのデザインを検索密 1 つのもの, 多機能で複雑なもの, 少数の 要素を持つ中間のものの 3 種類を提示し， 利用者に選ばせたところ, 最も多機能で複 雑なものが最も人気があったと述べられて いる.これは，利用者の行動と口頭での結 果が異なるものであり，実際の行動を見な ければ利用者の本当の要求は分からないこ とを示している.これは, ユーザ中心設計 のアプローチの重要性 , すなわち本研究の 検索行動調査の必要性について強く示唆す るものである .

本研究の行なった調査は被験者や検索課 題の数の少なさから，検索プロセスの特性 についての類型化には至っていない .これ
に対して，SCOPUS の調査では，オンライ ン・リソースを利用する際の研究者のタス クを研究者の行動の観察から $5 つ$ つ分類し ている.この結果は検索インタフェースに 関しても重要な示唆を与えており, 今後 利用者や検索課題の検討を重ね，調査を継 続する必要性を示している。

一方で, SCOPUS の対象としている情報 資源は, 基本的に自然科学系の文献データ であり，比較的統制の取れた情報資源であ ると言える．原本資料，ものデータ，歴史 史料といった多樣な情報資源を扱うために はSCOPUS の調査結果のみでは十分でな く,やはり, 人文科学系の研究資料の共有 化システムで直接利用者行動を観察する必 要性があると考える.本研究は, SCOPUS にみられる利用者中心設計を人文科学系の 研究資源共有化システムに応用するための 第一歩である .今後, SCOPUS のような大 規模な調査を人文科学系の研究領域におい て行なっていく必要性があるだろう.

\section{5 おわりに}

本研究では, 資源共有システムにおける 情報提供法を検討するために，検索行動調 査を行ない, 利用者の検索行動の詳細な分 析を行なつた . 調査は , 検索プロセスの記録 をとると同時に，インタビューと発話分析 を組合せ , 利用者がどのような要求をもつ てシステムを利用するのかを明らかにする ことを目的とした .特に検索エレメントの 使用方法と午の理由に焦点をあてることで 資源共有システムの検索インタフェースに 対する具体的な問題の発掘と改善方法を明 らかにすることを目指した .

高の結果 , 全ての検索エレメントをまと めて検索できる ANY は重要であり，検索 インタフェースに採用することが妥当であ ることが分かった . また, Titleや Creator 
などのように意味内容が比較的分かりやす いエレメントは炎のままでも十分効果的に 利用されること，Subjectや Description な どのように内容に関する検索を期待できる エレメントは必要であることが分かった . 一方，使用されなかったエレメントにも， Date のように使い方さえ分かれば効果的 に利用される可能性のあるものが含まれて いることも判明した .

一方で, 対象とするデータによってキー ワードと検索エレメントとの対応関係をと ることか灘しい場合や, 利用者の検索経験 が浅い場合には，個別のエレメントを提示 することが利用者の混乱を招くことが分か つた .このような場合には分かりやすい説 明やデータの例を提示するなど, エレメン 卜の理解を助ける工夫が必要であることな どが明らかとなった .

本研究による知見は, 今回の実験システ ムである Dublin Core による検索エレメン 卜を採用したシステムに限らず，OPACな ども含む一般的なメタデータによる検索シ ステムに共通して言えることであると考え ている . 全ての検索エレメントを区別なく 検索できるような簡易インタフェースは必 要であるが, 一方で, 個別のエレメントも 重要であることが今回の調査で明らかとな つた . 兴のような個別エレメントを含むイ ンタフェースを設計する際に，エレメント の曖昧性, 情報資源の性質, 対象とする利 用者の経験にあわせて説明や例示を与える などの支援が必須であるといえる .

今後の課題は, 調査対象と検索課題を増 やすことにより利用者の特徵をとらえ類型 化することである .これにより，利用者の 特徵にあわせた検索エレメントセットの自 動抽出を行ないインタフェースを生成する システムを実現することである .

\section{謝辞}

本研究は, 国文学研究資料館の共同研究 「文化情報資源の共有化システムに関する 研究」の一貫として行なった .議論の中で 貴重な二意見と知見を与えて頂いた研究グ ループの各位に深く感謝する．

\section{参考文献}

[1] 安永尚志 (編) . 2003 年度総合研究大 学院大学共同研究プロジェクト「文化 科学研究分野における情報資源共有化 のためのコラボレーション研究」第 1 回研究集会報告書. 国文学研究資料館, 2005.

[2] 安永尚志 (編) . 第 2 回資源共有化に 関する研究集会報告書. 国文学研究資 料館, 2005.

[3] Dublin Core Metadata Initiative. "Dublin Core Metadata Element Set, Version 1.1", 2006.

http://dublincore.org/documents/dces/ (最終確認 2007-02-05).

[4] 原正一郎; 相田満; 入口敦志; 江戶英 雄; 五島敏芳; 山田直子.「データベー ス共有におけるデータマッピングの事 例研究」. 情報処理学会研究報告, Vol. 2005, No. 76, pp. 31-38, 2005.

[5] 安達文夫; 鈴木卓治; 小島道裕; 高橋 一樹.「資源共有化のための歴史資料 データベースの Dublin Coreへのマッ ピングの検討」. 情報処理学会研究報 告, Vol. 2005, No. 76, pp. 39-46, 2005.

[6] 山本泰則; 中川隆.「データベース横 断検索のための民族学標本資料情報の Dublin Core による記述」。情報処理 学会研究報告, Vol. 2005, No. 76, pp. 47-54, 2005. 
[7] 岡本真. 「利用者の目から見た図書 館の目録-評価する点, 改善すべき点， 期待する点一」. 現代の図書館, Vol. 41, No. 4, pp. 217-221, 2003.

[8] 池田祥子.「利用者の情報探索行動に みる「主題」の概念-都立图書館 OPAC のログ解析を通して-」. 2002 年度三 田図書館·情報学会研究大会発表論文 集, pp. 5-8, 2002.

[9] Jansen, B. and Spink, A. "An analysis of Web documents retrieved and viewed". The 4th International Conference on Internet Computing. Las Vegas, Nevada, pp. 65-69, 2003.

[10] 野末道子; 嶋田真智恵; 寺尾洋子; 森岡 倫子; 上田修一.「OPAC ログ分析に よる検索過程の類型化」. 2004 年度三 田図書館·情報学会研究大会発表論文 集, pp. 41-44, 2004.

[11] 宍戶奈実. 「大学図書館における OPAC の利用者の探索行動: 学生を対 象としたインタビュー」. Library Information Science, No. 37, pp. 35-53, 1997.

[12] 齋藤ひとみ; 三輪和久.「WWW の情 報検索における人間の行動プロセスの 実験的検討」。電子情報通信学会技術 研究報告 ET 教育工学. Vol. 101, No. 115, pp. 23-28, 2001.
[13] 種市淳子; 逸村裕.「エンドユーザの Web 探索行動: 短期大学生の実験調査 にもとづく情報評価モデルの構築」。 Library Information Science, No. 55, pp. 1-23, 2006.

[14] 人間文化研究機構. $「\ulcorner$ 人文研究資源 共有化システム」分散型実証実験作業 報告書・調査報告書」, 2006.

[15] 国立情報学研究所. 「学術機関 リポジトリ構築ソフトウェア実装 実験プロジェクト報告書」, 2005. http://www.nii.ac.jp/metadata/irp/NIIIRPreport.pdf (最終確認 2007-01-15).

[16] Groot, de , S. P. and Knapp, A. E. "Applying the User-Centered Design (UCD) process to the development of a large bibliographic navigation tool: a partnership between librarian, researcher and developer". Scopus White Paper Series, no. 1, 2004. http://www.elsevier.com/framework librarians/WhitePapers/White_Paper_ 1_Usability_Testing.pdf（最終確認 2007-01-15).

(2006年10月6日受付) (2007年2月6日採択) 